\title{
Usaha Meningkatkan Efisiensi Sumber Daya Manusia Pada Kinerja Karyawan PT Indosat Tbk Palembang
}

\author{
Wendy Liana ${ }^{1)}$ \\ ${ }^{1)}$ Program Studi Administrasi Perkantoran, Akademi Sekretari dan Manajemen Sriwijaya \\ Jalan Letnan Murod No 35 KM 5 Palembang \\ Email : wendyliana80@yahoo.com ${ }^{1)}$
}

\begin{abstract}
The company is a form of formal organization and is a place where the system of cooperation is carried out in carrying out various activities as an effort to achieve certain goals. Many factors influence efforts to achieve the goals of a company. These factors are the resources owned by the company. Human resource performance can be measured from the quality of work produced, quantity of work that can be completed, timeliness to complete the work, and the effectiveness of employees using organizational resources. he development of science and technology, requires people to act more quickly and precisely by paying attention to efficiency in all fields, because the development of technology will require an organization to work professionally. It is very difficult for a company to achieve success without implementing office management effectively. Office management is very important to show how to go towards the implementation of a better job, namely by reducing barriers that may exist in a company in achieving its predetermined goals. Office management is an implementation process that can expedite the implementation of the leadership duties of a company in line with the increasing needs of every leader for complete and fast data in the decision making process needed. So the application of office management at any time will also provide a lot of assistance to the leadership. Office management is the pulse of all organizational activities and has a significant role in supporting the progress of a company. Office work means the activity of collecting, recording, processing, copying, sending and storing information.
\end{abstract}

Keywords : Efficiency, Performance, Human Resources, Office Management

\begin{abstract}
Abstrak
Perusahaan merupakan suatu bentuk organisasi formal dan merupakan wadah dimana sistem kerjasama dilakukan dalam melaksanakan berbagai aktivitas sebagai upaya untuk mencapai tujuan tertentu yang telah ditetapkan terlebih dahulu. Banyak faktor yang yang mempengaruhi upaya untuk mencapai tujuan dari suatu perusahaan. Faktor-faktor tersebut adalah sumber daya yang dimiliki oleh perusahaan. Kinerja sumber daya manusia dapat diukur dari kualitas pekerjaan yang dihasilkan, kuantitas (jumlah) pekerjaan yang dapat diselesaikan, ketepatan waktu untuk menyelesaikan pekerjaan tersebut, dan efektifitas karyawan menggunakan sumber daya organisasi. Semakin berkembangnya ilmu pengetahuan dan teknologi, menuntut manusia untuk bertindak semakin lebih cepat dan tepat dengan memperhatikan efisiensi disegala bidang, sebab perkembangan teknologi akan menuntut suatu organisasi harus bekerja secara profesional. Sulit sekali bagi suatu perusahaan untuk mencapai sukses tanpa pelaksanaan manajemen perkantoran secara efektif. Manajemen perkantoran sangat penting untuk menunjukkan cara bagaimana menuju kearah pelaksanaan pekerjaan yang lebih baik, yaitu dengan mengurangi hambatan-hambatan yang mungkin terdapat pada suatu perusahaan dalam mencapai tujuan yang telah ditetapkan terlebih dahulu. Manajemen perkantoran adalah proses penyelenggaraan yang dapat melancarkan pelaksanaan tugas pimpinan dari suatu perusahaan sejalan dengan meningkatnya kebutuhan setiap pimpinan akan data-data yang lengkap dan cepat dalam proses pengambilan keputusan yang dibutuhkan. Maka penerapan manajemen perkantoran setiap waktu juga akan banyak memberikan bantuan-bantuan terhadap pimpinan. Manajemen perkantoran merupakan urat nadi dari segala kegiatan organisasi dan memiliki peranan yang cukup besar dalam mendukung maju mundurnya suatu perusahaan. Pekerjaan kantor berarti kegiatan mengumpulkan, mencatat, mengolah, menggandakan, mengirim dan menyimpan keterangan.
\end{abstract}

Kata kunci : Efisiensi, Kinerja, Sumber Daya Manusia, Manajemen Perkantoran. 


\section{Pendahuluan}

Perusahaan merupakan suatu bentuk organisasi formal dan merupakan wadah dimana sistem kerjasama dilakukan dalam melaksanakan berbagai aktivitas sebagai upaya untuk mencapai tujuan tertentu yang telah ditetapkan terlebih dahulu. Banyak faktor yang yang mempengaruhi upaya untuk mencapai tujuan dari suatu perusahaan. Faktor-faktor tersebut adalah sumber daya yang dimiliki oleh perusahaan.

Peranan manajemen perkantoran sangat dibutuhkan oleh semua bentuk organisasi baik perusahaan, instansi pemerintah ataupun badan usaha lainnya. Dalam manajemen perkantoran, semua pelaksanaan kegiatan kantor tidak terlepas dari penerapan fungsi-fungsi manajemen. Tanpa adanya penerapan manajemen perkantoran yang baik, maka tidak mungkin usaha yang dijalankan oleh badan usaha tersebut dapat mengalami perkembangan kearah yang lebih maju.

Oleh karena itu, semakin berkembangnya ilmu pengetahuan dan teknologi, menuntut manusia untuk bertindak semakin lebih cepat dan tepat dengan memperhatikan efisiensi disegala bidang, sebab perkembangan teknologi akan menuntut suatu organisasi harus bekerja secara profesional. Sulit sekali bagi suatu perusahaan untuk mencapai sukses tanpa pelaksanaan manajemen perkantoran secara efektif. Manajemen perkantoran sangat penting untuk menunjukkan cara bagaimana menuju kearah pelaksanaan pekerjaan yang lebih baik, yaitu dengan mengurangi hambatanhambatan yang mungkin terdapat pada suatu perusahaan dalam mencapai tujuan yang telah ditetapkan terlebih dahulu.

Manajemen perkantoran adalah proses penyelenggaraan yang dapat melancarkan pelaksanaan tugas pimpinan dari suatu perusahaan sejalan dengan meningkatnya kebutuhan setiap pimpinan akan data-data yang lengkap dan cepat dalam proses pengambilan keputusan yang dibutuhkan. Maka penerapan manajemen perkantoran setiap waktu juga akan banyak memberikan bantuan-bantuan terhadap pimpinan. Manajemen perkantoran merupakan urat nadi dari segala kegiatan organisasi dan memiliki peranan yang cukup besar dalam mendukung maju mundurnya suatu perusahaan.

Pekerjaan kantor berarti kegiatan mengumpulkan, mencatat, mengolah, menggandakan, mengirim dan menyimpan keterangan. Pada kenyataannya, pelaksanaan kegiatan dapat diadakan dengan menggunakan mesin, alat hitung atau cara lain yang dikerjakan dengan manual, dengan maksud dan tujuan yang tetap sama yaitu membuat atau menyediakan informasi yang berguna untuk semua pihak. Luas sempitnya pekerjaan kantor berfungsi memberi fasilitas kepada pelaksana tugas pokok suatu instansi atau perusahaan, melayani, dan memudahkan koordinasi terhadap kegiatan-kegiatan pokok. Pekerjaan kantor mempunyai peranan dalam kehidupan dan perkembangan organisasi.

Sebagai suatu keseluruhan, karena fungsinya sebagai pusat ingatan, pusat kegiatan dan sumber dokumen.
Dalam menyelenggarakan kegiatan, perlu adanya pencatatan.

Berdasarkan uraian di atas, maka penulis tertarik untuk melakukan penelitian di PT Indosat Tbk Palembang, khususnya yang berkaitan dengan usaha meningkatkan efisiensi sumber daya manusia.

\section{A. Perumusan Masalah}

Perumusan masalah yang diajukan dalam penelitian ini didasarkan pada uraian- uraian diatas adalah sebagai berikut:

1. Metode apasaja yang diterapkan untuk meningkatkan efisiensi kinerja karyawan PT Indosat Tbk ?

2. Bagaimana peran PT Indosat Tbk dalam Meningkatkan efisiensi kinerja karyawan?

\section{B. Tujuan Penelitian}

Tujuan yang akan dicapai pada penelitian ini adalah:

1. Diharapkan dengan adanya penerapan dalam meningkatkan efisiensi kinerja karyawan akan memberikan sumbangan pemikiran bagi perusahaan untuk meningkatkan keterampilan karyawan.

2. Mengetahui bagaimana cara penerapan dalam meningkatkan efisiensi kinerja sehingga tercapai tujuan perusahaan?

\section{Manfaat Penelitian}

Manfaat penelitian ini adalah sebagai berikut:

1. Secara Teoritis

Penelitian ini diharapkan dapat menyumbangkan pengembangan keilmuan untuk peneliti selanjutnya, terutama yang berhubungan dengan peningkatan kinerja perusahaan tersebut.

2. Secara Praktis

Menambah khasanah keilmuan khususnya manajemen sumber daya manusia, yang berkaitan dengan usaha meningkatkan efisiensi sumberdayamanusia pada kinerja karyawan khususnya di perusahaan telekomunikasi dan perusahaan di bidang lainnya umumnya di Palembang.

\section{Pembahasan}

\section{A. Kinerja Karyawan}

Kinerja merupakan suatu fungsi dari motivasi dan kemampuan. Untuk menyelesaikan tugas dan pekerjaan seseorang, sepatutnya memiliki derajat kesediaan dan tingkat kemampuan tertentu. Kesediaan dan keterampilan seseorang tidaklah cukup efektif untuk mengerjakan sesuatu tanpa pemahaman yang jelas tentang apa yang akan dikerjakan dan bagaimana mengerjakannya. Kinerja karyawan merupakan suatu hal yang sangat penting dalam upaya perusahaan untuk mencapai tujuannya. Kinerja seorang karyawan merupakan hal yang bersifat individual, karena setiap karyawan mempunyai tingkat kemampuan yang berbeda-beda dalam mengerjakan tugasnya.

Pihak manajemen dapat mengukur karyawan atas unjuk kerjanya berdasarkan kinerja dari masing-masing karyawan. Kinerja adalah sebuah aksi, bukan kejadian. 
Aksi kinerja itu sendiri terdiri dari banyak komponen dan bukan merupakan hasil yang dapat dilihat pada saat itu juga. Pada dasarnya kinerja merupakan sesuatu hal yang bersifat individual, karena setiap karyawan memiliki tingkat kemampuan yang berbeda dalam mengerjakan tugasnya. Kinerja tergantung pada kombinasi antara kemampuan, usaha dan kesempatan yang diperoleh. Hal ini berarti bahwa kinerja merupakan hasil kerja karyawan dalam bekerja untuk periode waktu tertentu dan penekanannya pada hasil kerja yang diselesaikan karyawan dalam periode waktu tertentu.

Kinerja karyawan sering diartikan sebagai pencapaian tugas, di mana karyawan dalam bekerja harus sesuai dengan program kerja organisasi untuk menunjukkan tingkat kinerja organisasi dalam mencapai visi, misi dan tujuan organisasi. Kinerja karyawan adalah tingkat terhadapnya para karyawan mencapai persyaratan pekerjaan (Simamora, 2004).

Menurut Mangkunegara (2009:17) mengemukakan bahwa kinerja sumber daya manusia (SDM) merupakan istilah yang berasal dari kata job performance (prestasi kerja atau prestasi sesungguhnya yang dicapai seseorang). Harsuko (2011) mendefinisikan kinerja adalah unsur pencatatan hasil kerja SDM dari waktu kewaktu sehingga diketahui sejauh mana hasil kerja SDM dan perbaikan apa yang harus di lakukan agar dimasa mendatang lebih baik. Untuk mencapai sasaran dan tujuan perusahaan, organisasi di susun dalam unitunit kerja yang lebih kecil, dengan pembagian kerja, sistem kerja dan mekanisme kerja yang jelas.

Kurniawan (2005:9) menyatakan bahwa kinerja merupakan penilaian atas kualitas pengelolaan dan kualitas pelaksanan tugas atau operasi organisasi. Kemudian Simamora (2004:16) memandang bahwa kinerja adalah tingkat terhadap mana para karyawan mencapai persyaratan-persyaratan pekerjaan. Secara umum dapat dikatakan bahwa, kinerja merupakan wujud atau keberhasilan pekerjaan seseorang atau organisasi dalam mencapai tujuannya. Hasil atau kinerja suatu organisasi dapat dicapai dengan baik antara lain atas pengaruh dari pembagian tugas, wewenang, dan tanggung-jawab yang jelas dari para peserta yang berkecimpung di dalam organisasi tersebut. Lebih lanjut Simamora (2004) menyatakan bahwa kinerja adalah tingkat kerja yang dicapai oleh seseorang dengan syaratsyarat yang telah ditentukan.

\section{B. Aspek-Aspek Kinerja Karyawan}

Mangkunegara (2006) mengemukakan aspek-aspek standar kinerja, yaitu :

1. Aspek kuantitatif meliputi:

a. Proses kerja dan kondisi pekerjaan.

b. Waktu yang dipergunakan atau lamanya melaksanakan pekerjaan.

c. Jumlah kesalahan dalam melaksanakan pekerjaan.

d. Jumlah dan jenis pemberian pelayanan dalam bekerja.

2. Aspek kualitatif meliputi:

a. Ketepatan kerja dan kualitas pekerjaan.

b. Tingkat kemampuan dalam bekerja. c. Dalam hal ini peneliti memilih aspek-aspek standar kinerja karyawan

Penggunaan untuk Pengembangan Penilaian kinerja dapat menjadi sumber informasi utama dan umpan balik bagi pegawai yang merupakan kunci bagi pengembangan diri pegawai dimasa mendatang. Saat pimpinan mengidentifikasi kelemahan, potensi dan kebutuhan pelatihan melalui umpan balik penilaian kinerja, pimpinan dapat member tahu pegawai mengenai kemajuan mereka, mendiskusikan keterampilan apa yang perlu pegawai kembangkan dan melaksanakan perencanaan pengembangan.

Peran pimpinan disini adalah sebagai pembina dan tugas pembina adalah memberikan penghargaan kinerja yang baik berupa pengakuan, menerangkan tentang peningkatan yang diperlukan dan menunjukkan pada pegawai bagaimana caranya meningkatkan diri. Tujuan dari umpan balik pengembangan adalah untuk mengubah atau mendorong tingkah laku seseorang dan bukan membandingkan individu-individu sebagaimana dalam kasus penggunaan administratif untuk penilaian kinerja. Bintoro (2017:32) menyatakan terdapat 5 (lima) metode penilaian kinerja pegawai, yaitu:

1) Rating Scale

Evaluasi hanya didasarkan pada pendapat penilai yang membandingkan hasil pekerjaan pegawai dengan kriteria yang dianggap penting bagi pelaksanaan pekerjaan.

\section{2) Checklist}

Metode ini bertujuan untuk mengurangi beban penilai dimana penilai tinggal memilih kalimat atau katakata yang menggambarkan kinerja pegawai. Penilai biasanya adalah atasan langsung dan adanya pemberian bobot menyebabkan dapat di skor.

Metode ini biasanya memberikan gambaran prestasi kerja secara akurat apabila daftar penilaian berisi itemitem yang memadai.

3) Critical Incident Method (metode peristiwa kritis)

Penilaian yang dilakukan berdasarkan catatan-catatan penilai yang menggambarkan perilaku pegawai sangat baik atau jelek dalam kaitannya dengan pelaksanaan kerja. Catatan-catatan ini disebut dengan peristiwa kritis. Metode ini sangat berguna dalam memberikan umpan balik kepada pegawai dan mengurangi kesalahan kesan terakhir.

d. Tes dan Observasi Prestasi Kerja

Metode ini dilakukan apabila jumlah pegawai terbatas dan penilaian prestasi kerja bisa didasarkan pada tes pengetahuan dan keterampilan. Tes tersebut dapat dalam bentuk tertulis maupun peragaan keterampilan.

e. Method Ranking

Berdasarkan beberapa pendapat ahli di atas dapat disimpulkan bahwa aspek-aspek kinerja karyawan adalah aspek kualitatif, aspek kuantitatif, ketepatan waktu, insitatif, kemampuan dan komunikasi.

\section{Penilaian Kinerja Karyawan}

Penilaian kinerja merupakan faktor kunci dalam mengembangkan potensi pegawai secara efektif dan efisien karena adanya kebijakan atau program yang lebih 
baik atas sumberdaya manusia yang ada di dalam suatu organisasi. Penilaian kinerja individu sangat bermanfaat bagi pertumbuhan organisasi secara keseluruhan.

Menurut Sedarmayanti (2011:261), mengemukakan bahwa penilaian kinerja adalah sistem formal untuk memeriksa dan mengevaluasi secara berkala kinerja seseorang.

Dari uraian di atas dapat disimpulkan bahwa penilaian kinerja pegawai sangat perlu dilakukakan, karena dapat dijadikan sebagai evaluasi terhadap setiap pegawai atasan dan bawahan sehingga tujuan instansi akan cepat tercapai.

Untuk mengukur kinerja seorang karyawan, terdapat 5 (lima) kriteria yang dihasilkan dari pekerjaannya, yaitu:

1. Kualitas, merupakan tingkatan dimana hasil akhir yang dicapai mendekati sempurna dalam arti memenuhi tujuan yang diharapkan

2. Kuantitas, adalah jumlah yang dihasilkan yang dinyatakan dalam istilah sejumlah unit kerja ataupun merupakan jumlah siklus yang dihasilkan.

3. Ketepatan waktu, tingkat aktivitas diselesaikannya pekerjaan tersebut pada waktu awal yang diinginkan.

4. Efektifitas, merupakan tingkat pengetahuan sumber daya organisasi dengan maksud menaikkan keuntungan.

5. Kemandirian, Karyawan dapat melakukan fungsi kerjanya tanpa bantuan dari orang lain. Mangkunegara (2010:45) menjelaskan aspek-aspek standar pekerjaan yang terdiri dari aspek kuantitatif dan aspek kualitatif.

a. Aspek kuantitatif meliputi:

1) Proses kerja dan kondisi pekerjaan

2) Waktu yang digunakan atau lamanya melaksanakan pekerjaan

3) Jumlah kesalahan dalam melaksanakan pekerjaan

4) Jumlah dan jenis pemberian pelayanan dalam bekerja.

b. Aspek kualitatif meliputi:

1) Ketepatan kerja dan kualitas pekerjaan

2) Tingkat kemampuan dalam bekerja

3) Kemampuan menganalisis data, menggunakan mesin.

4) Kemampuan mengevaluasi (keluhan/ keberatan konsumen)

Dari uraian di atas maka dapat disimpulkan bahwa kinerja sumber daya manusia dapat diukur dari kualitas pekerjaan yang dihasilkan, kuantitas (jumlah) pekerjaan yang dapat diselesaikan, ketepatan waktu untuk menyelesaikan pekerjaan tersebut, dan efektifitas karyawan menggunakan sumber daya organisasi.

\section{Meningkatkan Peran Perusahaan Dalam} Meningkatkan Efisiensi Kinerja Karyawan

PT. Indosat Tbk memiliki budaya bekerja yang memungkinkan karyawan lebih produktif dan menyenangkan dalam bekerja. Indosat berupaya menciptakan lingkungan kerja yang positif bagi seluruh karyawan. Tujuannya adalah untuk menyediakan lingkungan di mana karyawan dapat menikmati pekerjaan mereka dan saat bersamaan juga didorong memberikan kemampuan terbaik mereka.

Dengan jumlah jam kerja yang telah ditetapkan perusahaan, karyawan memiliki fleksibilitas untuk menyesuaikan jadwal masuk dan pulang kerja sesuai beban kerja masing-masing atau untuk mengakomodasi keperluan penting di luar kerja. Demikian pula, aturan berpakaian yang fleksibel memungkinkan karyawan untuk berpakaian formal atau santai sesuai dengan waktu kerja atau tuntutan pekerjaan mereka.

Peran penting Indosat dalam meningkatkan efisiensi kinerja karyawan tercermin oleh banyaknya inisiatif Sumber Daya Manusia (SDM). Inisiatif tersebut bertujuan untuk mencapai tujuan Indosat yaitu memiliki karyawan terbaik, dengan cara menciptakan budaya korporat yang mewujudkan nilai-nilai Indosat sehingga PT Indosat Tbk menjadi pelopor yang berinovasi.

\section{E. Kendala Yang di Hadapi PT Indosat Tbk Palembang}

1. Dalam meningkatkan efisiensi kinerja karyawan yang di terapkan pada PT Indosat Tbk karyawan di hadapkan untuk merubah pola kerja yang sebelumnya sudah biasa di lakukan menjadi Pola kerja baru yang lebih Efisien sesuai kebijakan Perusahaan agar mendapatkan cara yang lebih efektif dalam bekerja.

2. PT Indosat Tbk Palembang juga menuntut karyawan untuk tetap menjaga performansi kinerja yang baik ketika harus bertahap berpindah ke pola kerja baru yang lebih efisien.

3. Training di PT Indosat Tbk Palembang memiliki jangka waktu yang terbatas dan jika ada perubahan pola kerja yang baru maka karyawan harus cepat beradaptasi dengan pola kerja tersebut.

\section{F. Meningkatkan Kualitas SDM PT Indosat Dalam} Efisiensi Kinerja yang diterapkan Pada Perusahaan

1. Organisasi yang efektif.

Indosat terus menggandeng business user dalam upaya memetakan keperluan SDM di setiap departemen. Agar sumber daya dialokasikan dengan tepat kepada bagian-bagian bisnis yang mengalami pertumbuhan. Struktur organisasi ini bertujuan agar SDM dialokasikan dengan lebih efektif, sekaligus memperbaiki jalur pelaporan ke atasan dan meningkatkan produktivitas.

2. Pengembangan dan pelatihan karyawan.

3. Pelatihan dan pengembangan SDM adalah suatu kegiatan untuk meningkatkan kapasitas SDM agar bisa menjadi sumber daya yang berkualitas, baik dari segi pengetahuan, keterampilan bekerja, tingkat profesionalisme yang tinggi dalam bekerja agar bisa meningkatkan kemampuan untuk mencapai tujuantujuan perusahaan dengan baik.

4. Meningkatkan dan mempertahankan kualitas dan kuantitas hasil kerja performansi karyawan.

5. Menciptakan sumber daya manusia yang berkualitas dan menjadi sumber keunggulan perusahaan (center of excellence). Usaha untuk menciptakan sumber daya manusia yang berkualitas dan menjadi sumber keunggulan perusahaan ini dapat dilakukan salah satunya adalah dengan training dan sharing knowledge. 
6. Meningkatkan dan memelihara kesejahteraan pegawai. Untuk menciptakan sumber daya manusia yang berkualitas dengan performansi yang bagus, dilakukan usaha untuk meningkatkan dan memelihara kesejahteraan karyawan.

\section{G. Metode Penelitian}

1. Jenis Penelitian

Bentuk penelitian ini adalah penelitian kualitatif. Menurut Sugiyono (2013) bahwa metode penelitian adalah cara yang ilmiah digunakan untuk mendapatkan data dengan tujuan dan kegunaan tertentu. Menurut Meleong (2007) penelitian kualitatif adalah tradisi tertentu dalam ilmu pengetahuan sosial yang secara fundamental bergantung pada pengamatan terhadap manusia dalam kawasan sendiri dan berhubungan dengan orang-orang tersebut dalam bahasanya dan dalam peristilahannya. Peneliti berupaya untuk melakukan deskripsi mengenai peran PT Indosat Tbk dalam Meningkatkan efisiensi kinerja karyawan dan masalahmasalah yang dihadapi oleh pihak-pihak yang terkait secara mendalam oleh karena itu penelitian ini dilakukan dengan pendekatan kualitatif.

\section{Definisi Konsep}

Menurut Sugiyono (2013) bahwa konsep adalah istilah atau definisi yang digunakan untuk menggambarkan secara abstrak kejadian, keadaan, kelompok atau individu yang menjadi pusat perhatian ilmu sosial sehingga dengan konsep maka peneliti akan bisa memahami unsur-unsur yang ada dalam penelitian baik variabel, indikator, parameter maupun skala pengukuran yang dikehendaki dalam penelitian untuk dapat memahami batas yang lebih jelas maka dapat menyederhanakan pemikiran atas masalah yang sedang penulis teliti, maka peneliti mengemukakan konsepkonsep antara lain:

a. Menurut Soewarno (1990:15), efisiensi adalah perbandingan yang terbaik antara masukan (input) dan keluaran (output), atau antara daya usaha dan hasil, atau antara pengeluaran dan pendapatan. Dalam pengertian manajemen yang sehat sudah tersimpul pengertian efisiensi, dalam arti bahwa segala sesuatu dikerjakan dengan berdaya guna; artinya dengan tepat, cepat, hemat, dan selamat yang maksudnya sebagai berikut:

1) Tepat: kena sasaran, apa yang dikehendaki tercapai, atau apa yang dicita-citakan menjadi kenyataan.

2) Cepat: tidak menghabiskan waktu yang tidak perlu, selesai tepat pada waktunya atau sebelum waktu yang ditetapkan.

3) Hemat: dengan biaya yang sekecil-kecilnya, tanpa terjadi pemborosan dalam bidang apapun.

4) Selamat: segala sesuatu samapai pada tujuan yang dimaksud tanpa mengalami hambatan-hambatan, kelambatan-kelambatan, ataupun kemacetankemacetan.

b. Menurut Prawiro Suntoro (1999), kinerja adalah hasil kerja yang dapat dicapai seseorang atau sekelompok orang dalam suatu organisasi dalam mencapai tujuan organisasi dalam periode waktu tertentu.

\section{Key Informan}

Sangkayo (2012) mengatakan bahwa penelitian kualitatif tidak dimaksudkan untuk membuat generalisasi dari hasil penelitian yang dilakukan dengan subjek penelitian yang telah tercermin dalam fokus penelitian ditentukan secara sengaja. Subjek penelitian inilah yang akan menjadi informasi yang akan memberikan berbagai informasi yang diperlukan selama proses penelitian.

Berdasarkan uraian di atas, maka peneliti menentukan informasi dengan menggunakan teknik pursosive sampling yaitu pengambilan sampel sumber data secara sengaja dan dengan pertimbangan tertentu pertimbangan itu misalnya orang tersebut dianggap paling tahu tentang apa yang kita hadapi atau mungkin dia sebagai pengusaha sehingga akan memudahkan penelitian menjelajah objek situasi sosial yang akan diteliti. Dalam penelitian ini, maka yang menjadi informasi adalah pihak manajemen PT Indosat Tbk Palembang.

4. Jenis Data dan Sumber Daya

a. Data Primer

Merupakan data yang berasal dari jawaban atas kuesioner atau wawancara langsung pada pihak manejemen PT Indosat Tbk Palembang.

b. Data Sekunder

Merupakan data yang diperoleh dengan cara pengutip dari sumber-sumber lain seperti buku-buku peraturan tertulis, undang-undang serta laporan-laporan yang berkaitan dengan penelitian ini.

c. Unit Analisis

Unit penelitian ini adalah unit analisis atau unit diteliti. Menurut Djarwanto PS dan Pangestu Subagyo (1993) bahwa unit analisis adalah satuan-satuan atau individu yang hendak diduga. Dalam penelitian ini unit analisis adalah organisasi, yaitu PT Indosat Tbk Palembang

c. Teknik Pengumpulan Data

1) Dokumentasi

Dokumentasi adalah mencari data mengenai hal-hal atau variabel berupa catatan, transkrip, buku, surat kabar majalah, prasasti, notulen, rapat, legenda, agenda, dan sebagainya dalam penelitian yang dilakukan dengan menyeleksi terhadap dokumen terkait.

\section{2) Wawancara}

Wawancara merupakan cara untuk memperoleh informasi dengan bertanya secara langsung dengan mengajukan pertanyaan-pertanyaan secara langsung dan mendalam serta terbuka kepada informan atau pihak yang berhubungan dengan penelitian.

3) Observasi

Menurut Sugiyono (2013) bahwa observasi merupakan suatu proses yang kompleks suatu proses yang tersusun dari berbagai proses biologis. Dua di antara yang terpenting adalah proses-proses pengamatan dan proses melihat.

\section{d. Teknik Analisis Data}

Teknik analisis data yang digunakan dalam penelitian ini adalah teknik analisis kualitatif yaitu dengan menggambarkan keadaan subjek dan objek seseorang, 
lembaga, masyarakat dan lain-lain berdasarkan fakta yang ada.

Pendekatan kualitatif diperoleh dari data-data yang dikumpulkan melalui wawancara observasi dan studi kepustakaan, diolah dan dianalisis dengan tepat kemudian diinterprestasikan. Dalam penelitian jenis deskriptif ini, peneliti menerjemahkan dan mengurangi data secara kualitatif sehingga diperoleh gambaran mengenai situasi-situasi atau peristiwa-peristiwa terjadi, dan juga adanya dukungan data angka yang akan menambah keabsahan data yang ada.

\section{Kesimpulan}

Dalam proses Meningkatkan Efsisiensi kinerja Karyawan, PT Indosat Tbk Palembang tidak selalu memperhatikan jam kerja utama dan pembagian pola kerja baru dalam meningkakan Kinerja yang lebih efisien.

Training di PT Indosat Tbk Palembang memiliki jangka waktu yang terbatas dan jika ada perubahan pola kerja yang baru maka Karyawan harus cepat beradaptasi dengan pola kerja tersebut.

Dari pengamatan penulis tentang usaha meningkatkan efsisiensi kinerja karyawan membutuhkan proses adaptasi dari pola kerja yang lama ke pola kerja baru yang lebih Efisien dan Karyawan dituntut tetap menjaga Performansi kinerja nya.

Untuk masalah persaingan di bidang komunikasi PT Indosat Tbk Palembang harus memberikan karyawan pola kerja yang efisensi agar seluruh karyawan bisa berinovasi untuk kemajuan perusahaan.

\section{Saran}

1. Dalam proses meningkatkan kinerja karyawan yang lebih efisien seharusnya PT Indosat Tbk Palembang melakukan pembagian waktu adaptasi yang tepat dalam membagi pola kerja dari pola kerja yang lama ke pola kerja baru yang lebih efisien sesuai kebijakan perusahaan.

2. Ada baiknya jika pihak perusahaan melakukan evaluasi terhadap pola kerja yang lama dengan berkoordinasi dengan karyawan dan membandingkan pola kerja yang lama dengan pola kerja yang baru agar tujuan perusahaan tercapai.

3. Diharapkan PT Indosat Tbk Palembang dapat membuat program training rutin kepada karyawan guna meningkatkan skill dan keahlian serta menambah pengetahuan yang bermanfaat bagi karyawan

4. PT Indosat Tbk Palembang harus tetap berinovasi dibidang telekomunikasi agar tidak kalah bersaing dengan perusahaan telekomunikasi besar lainnya dan tetap agar Indosat tetap mencapai tujuan dari visi dan misinya.

\section{Daftar Pustaka}

Bintoro, Daryanto. 2017. Manajemen Penilaian Kinerja Karyawan. Jakarta: Gava Media.

Budiharjo, M. 2015. Panduan Praktis Penilaian Kinerja Karyawan. Jakarta: Rah Ara Sukses.

Djarwanto PS dan Pangestu Subagyo. 1993. Statistik Indukatif Edisi Pertama. BPFE. Yogyakarta

Doni Juni Priansa. 2014. Perencanaan dan Pengembangan SDM. Bandung: Alfabeta.

Kaswan, 2016. Pelatihan dan Pengembangan untuk Meningkatkan Kinerja SDM. Bandung: Alfabeta.

Meleong, Lexy J. 2007. Metodologi Penelitian Kualitatif. PT Remaja Rosdakarya. Bandung

Sangkayo, Hendro, 2012. Metodologi Penelitian Kualitatif. PT Remaja Rosdakarya. Bandung

Sugiyono. 2013. Metode Penelitian Pendidikan Pendekatan Kuantitatif, Kualitatif, dan R\&D. CV Alfabeta. Bandung

Sedarmayanti, 2017. Perencanaan dan Pengembangan Sumber Daya Manusia untuk Meningkatkan Kompetensi Kinerja dan Produktivitas kerja.

Sutrisno, Edy. 2014. Manajemen Sumber Daya Manusia. Jakarta: Kencana Prenada Media Group.

Sondang P. Siagiaan. 2015. Manajemen Sumber Daya Manusia. Jakarta: Bumi Aksara.

https://indosatooredoo.com/id/personal

https://id.wikipedia.org/wiki/Indosat_Ooredoo 